\title{
XPS-Characterization of Heterometallic Coordination Compounds with Optically Active Ligands
}

\author{
Yenny Ávila-Torres, ${ }^{1}$ Lázaro Huerta, ${ }^{2}$ and Noráh Barba-Behrens ${ }^{1}$ \\ ${ }^{1}$ Departamento de Química Inorgánica, Facultad de Química, Universidad Nacional Autónoma de México, C. U., Coyoacán, \\ 04510 Mexico, DF, Mexico \\ ${ }^{2}$ Instituto de Investigaciones en Materiales, Universidad Nacional Autónoma de México, C. U., Coyoacán, 04510 Mexico, DF, Mexico \\ Correspondence should be addressed to Yenny Ávila-Torres; yavilatorres@gmail.com
}

Received 14 March 2013; Revised 9 May 2013; Accepted 23 May 2013

Academic Editor: Tsun-Ren Chen

Copyright (C) 2013 Yenny Ávila-Torres et al. This is an open access article distributed under the Creative Commons Attribution License, which permits unrestricted use, distribution, and reproduction in any medium, provided the original work is properly cited.

The heterometallic optical complexes $\left[\mathrm{Cu}_{2} \mathrm{Co}(\mathrm{S}, \mathrm{S}(+) \mathrm{cpse})_{3}\left(\mathrm{H}_{2} \mathrm{O}\right)_{3}\right] \cdot 4 \mathrm{H}_{2} \mathrm{O}(\mathbf{1})$ and $\left[\mathrm{Cu}_{2} \mathrm{Ni}(\mathrm{S}, \mathrm{S}(+) \mathrm{cpse})_{3}\left(\mathrm{H}_{2} \mathrm{O}\right)_{3}\right] \cdot 10 \mathrm{H}_{2} \mathrm{O}(\mathbf{2})$ were obtained from the mononuclear copper(II) compound by the addition of nickel(II) or cobalt(II) chlorides, where $\left(\mathrm{H}_{2} \mathrm{cpse}\right)$ is the acetyl amino alcohol derivative $\mathrm{N}$-[2-hydroxy-1 $(R)$-methyl-2(R)-phenylethyl]-N-methylglycine. In comparison with the homotrinuclear copper(II) compound $\left[\mathrm{Cu}_{3}(\mathrm{~S}, \mathrm{~S}(+) \mathrm{cpse})_{3}\left(\mathrm{H}_{2} \mathrm{O}\right)_{3}\right] \cdot 8 \mathrm{H}_{2} \mathrm{O}$ reported previously, the substitution of a copper(II) atom by one cobalt(II) ion gave place to a heterotrinuclear compound 1, which presents ferromagnetic-antiferromagnetic behaviour. When substituting a copper(II) by a nickel(II) ion, the trinuclear compound 2 showed an antiferromagnetic coupling. The magnetic behaviour of the heterotrinuclear compounds is driven by the nature of the metal ion which was introduced in the copper(II) triangular array. The ligand and its coordination compounds were characterized by IR, UV-Vis-NIR. Their chemical was confirmed by photoelectron spectroscopy (XPS).

\section{Introduction}

Investigation of novel inorganic-organic compounds mixed represents one of the most active areas of materials science and chemical research. The structural diversity of compounds bearing with more than one metal ion may give place to potential applications in research fields such as electrical conductivity, magnetism, photomechanism, host-guest chemistry, ion exchange, shape specificity, and catalysis $[1,2]$.

Mixed metal states can allow access to several electronic states and cooperative effects between them [3]. There is a particular emphasis on heterobimetallic complexes, and much of this research has been directed towards transition metal clusters. High-spin multiplicity in a polymetallic entity could be stabilized without imposing ferromagnetic interactions between the nearest magnetic centers. To achieve this, two high local spins are aligned in the same direction due to antiferromagnetic interactions with a small spin located between them [4-6].
Chiral ligands have been used in the formation of an extended homochiral two-dimensional (2D) sheet, which, in turn, leads to a conglomerate structure, constructed through the homochiral stacking of the 2D sheets [7]. Also, such photochemical switches controlled by photoisomerization can be used in the formation of cholesteric phases on nematic hosts and helical pitches [8]. In the technological field, chiral magnet may participate in the process for storage information and gas storage $[9,10]$.

The d-block metal ions are borderline acids, having a strong tendency to coordinate with $\mathrm{N}$-donors as well as O-donors [11]. The acetyl pseudoephedrine derivative $S, S(+)$. $\mathrm{H}_{2}$ cpse is a flexible enantiomerically pure ligand, with three potential coordination sites: the nitrogen which is an atom, and the carboxylic and the alcohol groups and (Figure 1).

In this work, we present the synthesis of the heterotrinuclear compounds $\left[\mathrm{Cu}_{2} \mathrm{Ni}(\mathrm{S}, \mathrm{S}(+) \text { cpse })_{3}\left(\mathrm{H}_{2} \mathrm{O}\right)_{3}\right] \cdot 10 \mathrm{H}_{2} \mathrm{O} \quad \mathbf{1}$ and $\left[\mathrm{Cu}_{2} \mathrm{Co}(S, S(+) \mathrm{cpse})_{3}\left(\mathrm{H}_{2} \mathrm{O}\right)_{3}\right] \cdot 4 \mathrm{H}_{2} \mathrm{O}$ 2. The trinuclear bimetallic compounds are product of deprotonation of 


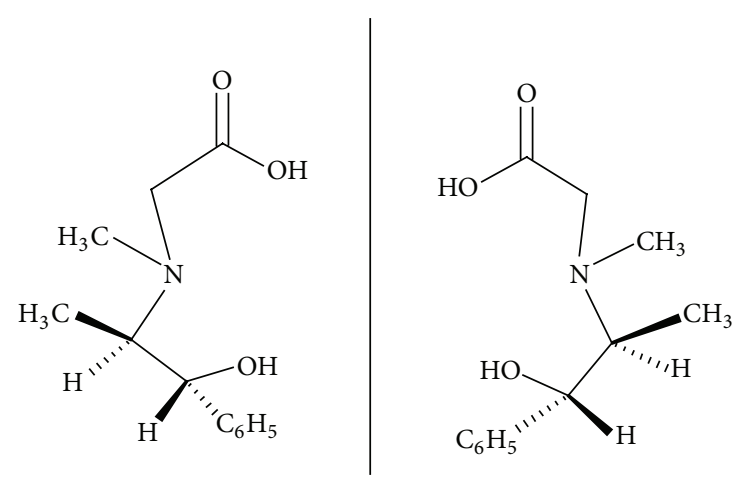

Figure 1: Structures for $\left(S, S(+) \mathrm{H}_{2}\right.$ cpse $)$.

the $\mathrm{OH}$ group in the mononuclear copper(II) compound $\left[\mathrm{Cu}(\mathrm{S}, \mathrm{S}(+) \mathrm{Hcpse})_{2}\right] \cdot 2 \mathrm{H}_{2} \mathrm{O}$, which gives place to an oxobridge between the metal ions [12]. They were spectroscopically characterized by IR, electronic absorption, atomic absorption, EPR, and magnetic susceptibility at variable temperature. Photoemission spectroscopy provided direct electronic information about core-level states at higher binding energies. The heterometallic compounds were spectroscopically compared with trinuclear copper(II) compound $\left[\mathrm{Cu}_{3}(\mathrm{~S}, \mathrm{~S}(+) \mathrm{cpse})_{3}\left(\mathrm{H}_{2} \mathrm{O}\right)_{3}\right] \cdot 8.5$ reported previously [13]. This characterization allowed us to understand structural similarities between homometallic and heterometallic compounds. Finally, it is considered that these results contributed significantly to the structural elucidation and the electronic structure of coordination compounds [14-16].

\section{Experimental Section}

2.1. General Remarks. IR spectra in the range $4000-400 \mathrm{~cm}^{-1}$ were recorded on a Nicolet FT-IR 740 spectrophotometer using $\mathrm{KBr}$ pellets. Electronic spectra (diffuse reflectance), were measured on a Cary 5E Uv-Vis-NIR spectrophotometer over the range $250-2500 \mathrm{~nm}\left(40000-4000 \mathrm{~cm}^{-1}\right)$. Elemental analyses were performed on a Fisons EA 1108 elemental analyser. The relationship between metal ions was performed in AA Varian model Spectra AA 20 plus calibrated using SPEX standards for each metal. All experiments were run 10 times to reduce random errors; the reported data are the average values with errors below $0.5 \%$. Magnetic susceptibility measurements were carried out with a pendulumtype magnetometer (MANICS DSM8) equipped with an Oxford CF 1200 S helium continuous-flow cryostat working in the temperature range $300-4 \mathrm{~K}$ in a magnetic field of 1.5 T. Diamagnetic corrections were estimated using Pascal constants. The chemical analysis was obtained using Xray photoelectron spectroscopy (XPS), with VG Microtech ESCA2000 Multilab UHV system, $\mathrm{K}_{\alpha} \mathrm{X}$-ray source $(\mathrm{h} v=$ $1486.6 \mathrm{eV}$ ), and CLAM4 MCD analyzer. XPS spectrum was obtained at $55^{\circ}$ from the normal surface in the constant pass analyzer energy mode (CAE), $\mathrm{E}_{0}=50$ and $20 \mathrm{eV}$ for survey and high resolution narrow scan. Peak positions were referenced to the background silver $3 \mathrm{~d}_{5 / 2}$ core level at $368.20 \mathrm{eV}$, having a FWHM of $1.10 \mathrm{eV}, \mathrm{Au} 4 \mathrm{f}_{7 / 2}$ in $84.00 \mathrm{eV}$, and $\mathrm{C}$ 1s hydrocarbon groups in $285.00 \mathrm{eV}$ central peak position. The XPS spectra were fitted with the program SDP v 4.1 [17]. The XPS error is considering a detection limit estimated to be $0.1 \%$ in mass and uncertain propagation. For deconvolution analysis the uncertain was estimated at $5 \%$. The valence band (VB) energy zone was obtained.

2.2. Materials. The metal salts $\mathrm{CoCl}_{2} \cdot 6 \mathrm{H}_{2} \mathrm{O}, \mathrm{NiCl}_{2} \cdot 6 \mathrm{H}_{2} \mathrm{O}, \mathrm{Cu}$ $(\mathrm{OAc})_{2} \cdot \mathrm{H}_{2} \mathrm{O}$, and methanol (J. T. Baker) were used without further purification.

The synthesis of the ligand $\mathrm{N}$-[2-hydroxy-1(S)-methyl$2(S)$-phenylethyl]-N-methylglycine $\left(S, S(+) \mathrm{H}_{2}\right.$ cpse $) \quad 2$ and $\left[\mathrm{Cu}(\mathrm{S}, \mathrm{S}(+) \mathrm{Hcpse})_{2}\right] \cdot 2 \mathrm{H}_{2} \mathrm{O}$ compound was carried out as previously described [18].

2.3. Synthesis of Compound $\left[\mathrm{Cu}(\mathrm{S}, \mathrm{S}(+) \mathrm{Hcpse})_{2}\right] \cdot 2 \mathrm{H}_{2} \mathrm{O} \cdot \mathrm{Cu}$ $\left(\mathrm{CH}_{3} \mathrm{COO}\right)_{2} \cdot 2 \mathrm{H}_{2} \mathrm{O}(249.3 \mathrm{mg}, 0.125 \mathrm{mmol})$ was added to a solution of $S, S(+) \mathrm{H}_{2}$ cpse $(479 \mathrm{mg}, 2.13 \mathrm{mmol})$ in methanol $(20 \mathrm{~mL})$. The mixture was stirred for 15 minutes. A blue precipitate appeared immediately, yield $77.8 \%$. Anal. Calcd. for $\mathrm{C}_{24} \mathrm{H}_{36} \mathrm{CuN}_{2} \mathrm{O}_{7}$ : C\%, 55.98; $\mathrm{H} \%$, 6.58; N\%, 5.27. Found: $\mathrm{C} \%$, 54.58; $\mathrm{H} \%, 6.87 ; \mathrm{N} \%, 5.30 . \operatorname{IR}\left(\mathrm{KBr} v / \mathrm{cm}^{-1}\right): 1612\left(v_{\text {as }} \mathrm{COO}^{-}\right)$, $1392\left(\nu_{\mathrm{s}} \mathrm{COO}^{-}\right) \Delta \nu=220 \mathrm{~cm}^{-1}[17]$.

2.4. Synthesis of Compound $\left[\mathrm{Cu}_{2} \mathrm{Co}\left(\mathrm{S}, \mathrm{S}(+)_{\mathrm{cpse}}\right)_{3}\left(\mathrm{H}_{2} \mathrm{O}\right)_{3}\right]$. $4 \mathrm{H}_{2} \mathrm{O}(\mathbf{1})$. To a solution in $\mathrm{MeOH}(20 \mathrm{~mL})$ of $[\mathrm{Cu}(S, S(+)$. Hcpse $\left.)_{2}\right] \cdot 2 \mathrm{H}_{2} \mathrm{O}(502 \mathrm{mg}, 1 \mathrm{mmol}), 2$ equivalents of $\mathrm{NaOH}$ $(82 \mathrm{mg})$ and $\mathrm{CoCl}_{2} \cdot 6 \mathrm{H}_{2} \mathrm{O}(0.238 \mathrm{~g}, 1 \mathrm{mmol})$ were added. A green-gray solid was obtained over a period of one week, yield 47.8\%. Anal. Calcd for $\mathrm{C}_{36} \mathrm{H}_{56} \mathrm{Cu}_{2} \mathrm{CoN}_{3} \mathrm{O}_{13}: \mathrm{C}, 46.75 ; \mathrm{H}, 6.10$; $\mathrm{N}, 4.54$. Exp.: C, 46.45; H, 6.71; N, 4.52. Atomic absorption: $\mathrm{Cu}$ : Co $1.78: 1.22$ (13.4598\%-8.1445\%). IR $\left(\mathrm{KBr} v / \mathrm{cm}^{-1}\right): 1632$ $\left(v_{\mathrm{as}} \mathrm{COO}^{-}\right)$and $1383\left(v_{\mathrm{s}} \mathrm{COO}^{-}\right), \Delta \nu=249 \mathrm{~cm}^{-1}$.

2.5. Synthesis of Compound $\left[\mathrm{Cu}_{2} \mathrm{Ni}\left(\mathrm{S}, \mathrm{S}(+)_{\mathrm{cpse}}\right)_{3}\left(\mathrm{H}_{2} \mathrm{O}\right)_{3}\right]$. $10 \mathrm{H}_{2} \mathrm{O}(2)$. To a solution in $\mathrm{MeOH}(20 \mathrm{~mL})$ of $[\mathrm{Cu}(S, S(+)$. Hcpse $\left.)_{2}\right] \cdot 2 \mathrm{H}_{2} \mathrm{O}(502 \mathrm{mg}, 1 \mathrm{mmol}), 2$ equivalents of $\mathrm{NaOH}$ $(82 \mathrm{mg})$ and $\mathrm{NiCl}_{2} \cdot 6 \mathrm{H}_{2} \mathrm{O}(245 \mathrm{mg}, 1 \mathrm{mmol})$ were added. A pale green precipitate was obtained over a period of one week, yield 58.5\%. Anal. Calcd for $\mathrm{C}_{36} \mathrm{H}_{74} \mathrm{Cu}_{2} \mathrm{NiN}_{3} \mathrm{O}_{22}$ : C, 39.78; $\mathrm{H}$, 6.86; N, 3.87. Exp.: C, 39.2; H, 5.36; N, 3.88. Atomic absorption $\mathrm{Cu}: \mathrm{Ni} 1.92: 1.08(15.6278 \%-8.7689 \%)$. IR $\left(\mathrm{KBr} v / \mathrm{cm}^{-1}\right): 1623$ $\left(v_{\mathrm{as}} \mathrm{COO}^{-}\right)$and $1377\left(v_{\mathrm{s}} \mathrm{COO}^{-}\right), \Delta \nu=246 \mathrm{~cm}^{-1}$.

\section{Results and Discussion}

3.1. Heterotrinuclear Compounds $\mathbf{1}$ and 2. When reacting the copper(II) mononuclear $\left[\mathrm{Cu}(\mathrm{S}, \mathrm{S}(+) \mathrm{Hcpse})_{2}\right] \cdot 2 \mathrm{H}_{2} \mathrm{O}$ (obtained as previously described) [17] in basic conditions, with cobalt(II) or nickel(II) chlorides, the corresponding heterotrinuclear compounds $\left[\mathrm{Cu}_{2} \mathrm{Co}(\mathrm{S}, \mathrm{S}(+) \mathrm{cpse})_{3}\left(\mathrm{H}_{2} \mathrm{O}\right)_{3}\right]$. $4 \mathrm{H}_{2} \mathrm{O}(\mathbf{1})$ and $\left[\mathrm{Cu}_{2} \mathrm{Ni}(\mathrm{S}, \mathrm{S}(+) \mathrm{cpse})_{3}\left(\mathrm{H}_{2} \mathrm{O}\right)_{3}\right] \cdot 9 \mathrm{H}_{2} \mathrm{O}$ (2) were obtained.

In these compounds the ligand is coordinated by the nitrogen atom, the carboxylic group and the alcohol group, as observed from their IR spectra [19], where the corresponding stretching bands are shifted to lower energies upon coordination to the metal ions (Table 1$)$. The $v(\mathrm{C}-\mathrm{OH})_{\text {st. }}$ is not 
TABLE 1: Selected IR bands for the ligand and its coordination compounds.

\begin{tabular}{lcccc}
\hline Coordinate compound and ligand & $\begin{array}{c}v_{\text {as }}\left(\mathrm{COO}^{-}\right)- \\
\left(\mathrm{cm}^{-1}\right)\end{array}$ & $\begin{array}{c}v_{\mathrm{s}}\left(-\mathrm{COO}^{-}\right) \\
\left(\mathrm{cm}^{-1}\right)\end{array}$ & $\begin{array}{c}\Delta v \\
\left(\mathrm{~cm}^{-1}\right)\end{array}$ & $\begin{array}{c}\nu(\mathrm{C}-\mathrm{OH})_{\text {st }} \\
\left(\mathrm{cm}^{-1}\right)\end{array}$ \\
\hline$S, S(+) \mathrm{H}_{2} \mathrm{cpse}^{18}$ & 1638 & 1385 & - & 1040 \\
{$\left[\mathrm{Cu}_{3}(\mathrm{~S}, \mathrm{~S}(+) \mathrm{cpse})_{3}\left(\mathrm{H}_{2} \mathrm{O}\right)_{3}\right] \cdot 8.5 \mathrm{H}_{2} \mathrm{O}$} & 1631 & 1385 & 246 & - \\
{$\left[\mathrm{Cu}_{2} \mathrm{Co}(\mathrm{S}, \mathrm{S}(+) \mathrm{cpse})_{3}\left(\mathrm{H}_{2} \mathrm{O}\right)_{3}\right] \cdot 4 \mathrm{H}_{2} \mathrm{O}(\mathbf{1})$} & 1632 & 1383 & 249 & - \\
{$\left[\mathrm{Cu}_{2} \mathrm{Ni}(S, S(+) \mathrm{cpse})_{3}\left(\mathrm{H}_{2} \mathrm{O}\right)_{3}\right] \cdot 10 \mathrm{H}_{2} \mathrm{O}(2)$} & 1623 & 1377 & 246 & - \\
\hline
\end{tabular}

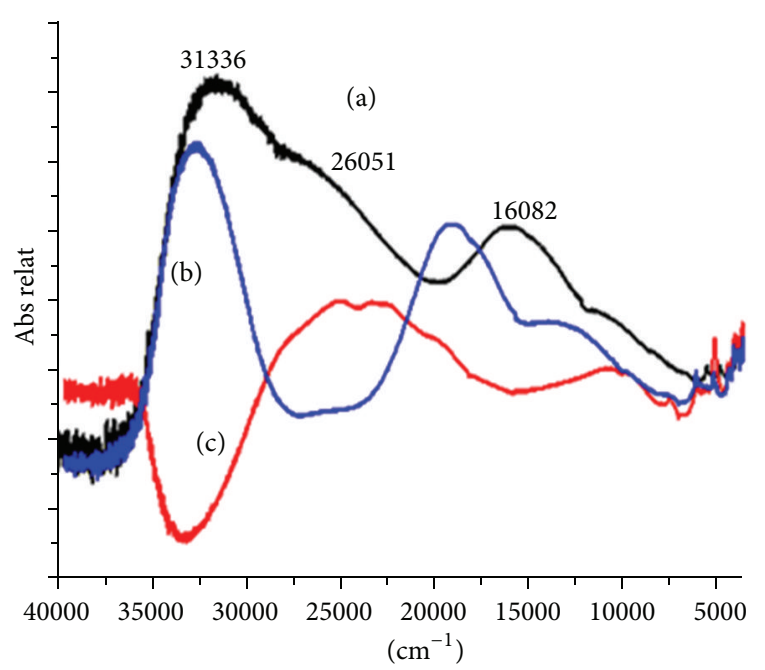

Figure 2: Electronic spectra for (a) $\left[\mathrm{Cu}_{2} \mathrm{Co}(S, S(+) \text { cpse })_{3}\left(\mathrm{H}_{2} \mathrm{O}\right)_{3}\right]$. $4 \mathrm{H}_{2} \mathrm{O}(1)$, (b) $\left[\mathrm{Cu}(S, S(+) \mathrm{cps})_{2}\right] \cdot 2 \mathrm{H}_{2} \mathrm{O}$, and (c) $\left[\mathrm{Co}(S, S(+) \mathrm{cps})_{2}\right]$. $2 \mathrm{H}_{2} \mathrm{O}$ synthetized previously.

observed due to deprotonation of the $\mathrm{OH}$ group and the bridging oxygen coordination to the metal centres.

In the electronic spectrum of $\left[\mathrm{Cu}_{2} \mathrm{Co}(S, S(+) \mathrm{cpse})_{3}\right.$. $\left.\left(\mathrm{H}_{2} \mathrm{O}\right)_{3}\right] \cdot 4 \mathrm{H}_{2} \mathrm{O} 1$, there are bands corresponding to $v_{1}=$ ${ }^{4} \mathrm{~A}_{2}^{\prime \prime}(\mathrm{F}) \leftarrow{ }^{4} \mathrm{~A}^{\prime}(\mathrm{F})=5933 \mathrm{~cm}^{-1}, \quad \nu_{2}={ }^{4} \mathrm{E}^{\prime}(\mathrm{F}) \leftarrow{ }^{4} \mathrm{~A}_{2}^{\prime}(\mathrm{F})=$ $8770 \mathrm{~cm}^{-1}$, and $\nu_{3}={ }^{4} \mathrm{E}^{\prime}(\mathrm{F}) \leftarrow{ }^{4} \mathrm{~A}_{2}^{\prime}(\mathrm{F})=16222 \mathrm{~cm}^{-1}$ for the cobalt(II) ion in a square-based pyramid geometry; the latter is a broad band which is superimposed with the expected transition for the copper(II) ion at ca. $14000 \mathrm{~cm}^{-1}$ [20]. Additionally, there is a CT M-L band at $31336 \mathrm{~cm}^{-1}$ (Figure 2). The spectrum was compared with the corresponding mononuclear compounds. The contribution of the copper(II) and cobalt(II) metal ions is observed in the electronic transitions.

The reflectance spectrum of the $\left[\mathrm{Cu}_{2} \mathrm{Ni}(S, S(+) \text { cpse })_{3}\right.$. $\left.\left(\mathrm{H}_{2} \mathrm{O}\right)_{3}\right] \cdot 10 \mathrm{H}_{2} \mathrm{O}$ compound 2 shows transitions in the near infrared that were assigned for a nickel(II) in a square-based pyramidal geometry, ${ }^{3} \mathrm{E}^{\prime} \leftarrow{ }^{3} \mathrm{E}$ at $5218 \mathrm{~cm}^{-1}$ and ${ }^{3} \mathrm{~A}^{2} \leftarrow{ }^{3} \mathrm{E}$ at $7047 \mathrm{~cm}^{-1}$; the rest of the expected transitions are overlapped with the copper(II) transition at $14285 \mathrm{~cm}^{-1}$, in the same region as for the trinuclear copper(II) $\left[\mathrm{Cu}_{3}(S, S(+)\right.$. cpse) $\left.{ }_{3}\left(\mathrm{H}_{2} \mathrm{O}\right)_{3}\right] \cdot 8 \mathrm{H}_{2} \mathrm{O}$ (Figure 3 ).

In accordance with the atomic absorption, elemental analysis, ultraviolet-infrared visible diffuse reflectance, and infrared spectroscopy, it is proposed that the heterotrinuclear compounds present a similar structure to that of

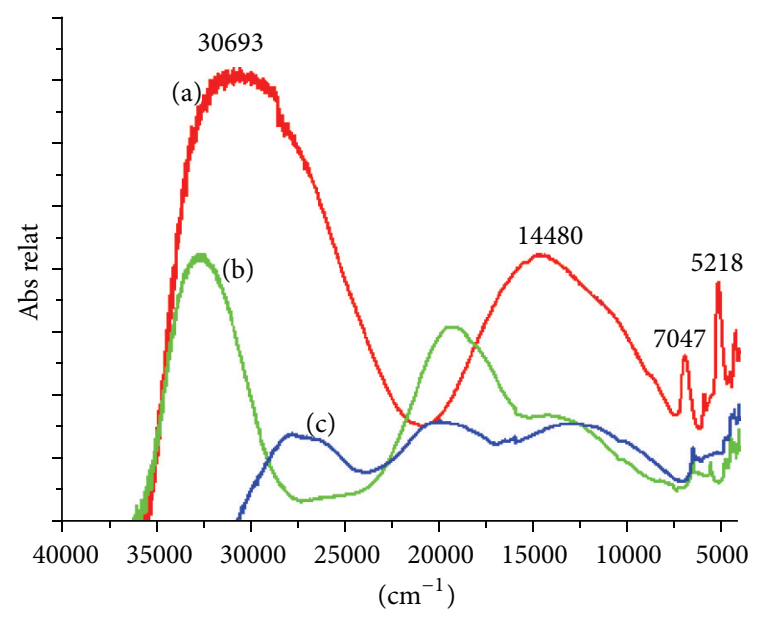

FIgURE 3: The UV-Vis-NIR electronic spectra for (a) $\left[\mathrm{Cu}_{2} \mathrm{Ni}(S\right.$, $S(+)$ cpse $\left.)_{3}\left(\mathrm{H}_{2} \mathrm{O}\right)_{3}\right] \cdot 10 \mathrm{H}_{2} \mathrm{O}(2),(\mathrm{b})\left[\mathrm{Ni}(S, S(+) \mathrm{cps})_{2}\right] \cdot 2 \mathrm{H}_{2} \mathrm{O}$ [17] and (c) $\left[\mathrm{Cu}(\mathrm{S}, \mathrm{S}(+) \mathrm{cps})_{2}\right] \cdot 2 \mathrm{H}_{2} \mathrm{O}[17]$.

$\left[\mathrm{Cu}_{3}(\mathrm{~S}, \mathrm{~S}(+) \text { cpse })_{3}\left(\mathrm{H}_{2} \mathrm{O}\right)_{3}\right] \cdot 8 \mathrm{H}_{2} \mathrm{O}$ reported previously [12]. This structure corresponds to three metal ions in a square pyramidal geometry; each of them coordinated with one molecule of the $S, S(+)$ cpse ligand and to a water molecule in the apical position. The metal centres are bridged by an oxygen atoms from the deprotonated $\mathrm{OH}$ group. In Figure 4 is shown the chemical structure for the heterometallic compounds. The supramolecular structure for $\left[\mathrm{Cu}_{3}(S, S(+) \mathrm{cpse})_{3}\right.$. $\left.\left(\mathrm{H}_{2} \mathrm{O}\right)_{3}\right] \cdot 8 \mathrm{H}_{2} \mathrm{O}$ presents interesting arrangements in the crystalline cell, due to the stabilization of a $\Delta$ isomer. In this system the $S, S(+)$ cpse and the metal ions contributed to the chirality (Figure 4 ).

In order to further corroborate the structure of the heterometallic compounds, a XPS study was performed for the three compounds. It compared the Survey XPS spectra of heterometallic compounds $\left[\mathrm{Cu}_{2} \mathrm{Co}(S, S(+) \text { cpse })_{3}\right.$. $\left.\left(\mathrm{H}_{2} \mathrm{O}\right)_{3}\right] \cdot 4 \mathrm{H}_{2} \mathrm{O}$ (1) $\left[\mathrm{Cu}_{2} \mathrm{Ni}\left(\mathrm{S}, \mathrm{S}(+) \mathrm{cpse}_{3}\left(\mathrm{H}_{2} \mathrm{O}\right)_{3}\right] \cdot 10 \mathrm{H}_{2} \mathrm{O}\right.$ (2) with those of $\left[\mathrm{Cu}_{3}(\mathrm{~S}, \mathrm{~S}(+) \text { cpse })_{3}\left(\mathrm{H}_{2} \mathrm{O}\right)_{3}\right] \cdot 8 \mathrm{H}_{2} \mathrm{O}$ (Figure 5). The electronic structure is similar to these compounds. It is observed that there are contributions for $\mathrm{Cu} 2 \mathrm{p}$ to $\left[\mathrm{Cu}_{3}(\mathrm{~S}, \mathrm{~S}(+) \text { cpse })_{3}\left(\mathrm{H}_{2} \mathrm{O}\right)_{3}\right] \cdot 8 \mathrm{H}_{2} \mathrm{O} ; \mathrm{Cu} 2 \mathrm{p}$ and $\mathrm{Co} 2 \mathrm{p}$ for $\left[\mathrm{Cu}_{2} \mathrm{Co}(\mathrm{S}, \mathrm{S}(+) \mathrm{cpse})_{3}\left(\mathrm{H}_{2} \mathrm{O}\right)_{3}\right] \cdot 4 \mathrm{H}_{2} \mathrm{O}(\mathbf{1})$; and $\mathrm{Cu} 2 \mathrm{p}$ and $\mathrm{Ni} 2 \mathrm{p}$ for $\left[\mathrm{Cu}_{2} \mathrm{Ni}(S, S(+) \mathrm{cpse})_{3}\left(\mathrm{H}_{2} \mathrm{O}\right)_{3}\right] \cdot 10 \mathrm{H}_{2} \mathrm{O}(2)$.

In XPS interpretation, the general rule is that the $\mathrm{BE}$ of the central atom increases as the electronegativity of the attached atoms or groups increases [21]. The difference on 

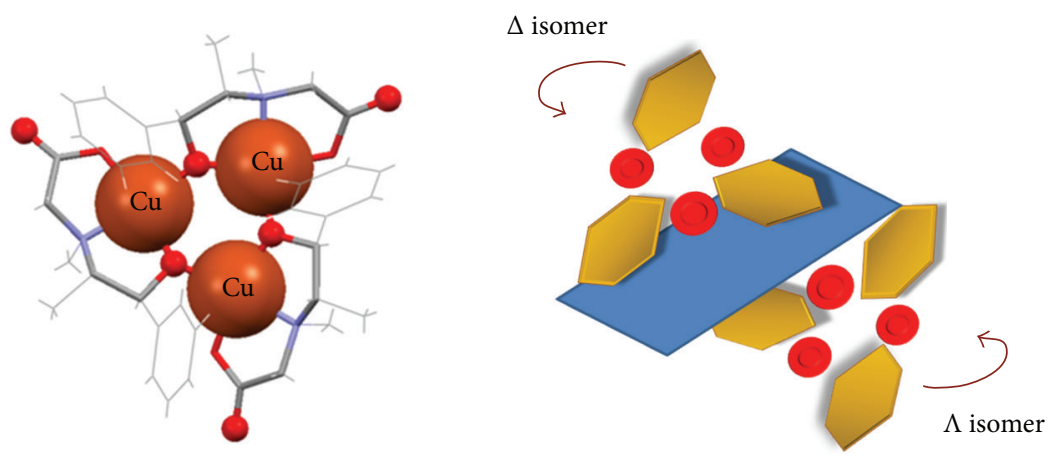

(a)

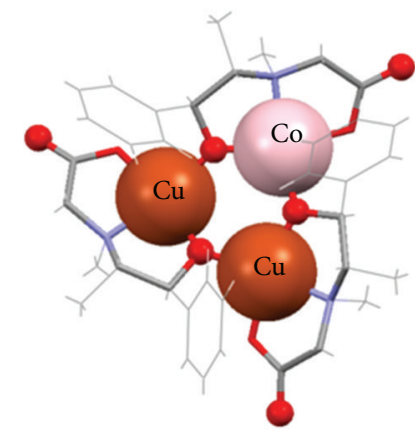

(b)

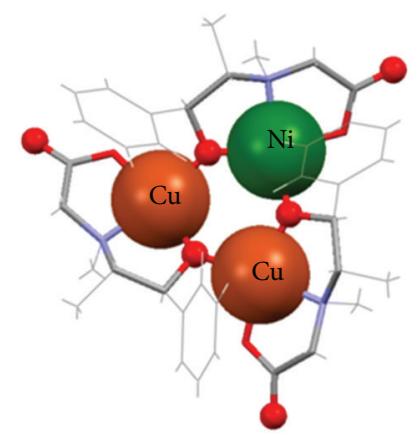

(c)

Figure 4: (a) Structure of the homotrinuclear $\left[\mathrm{Cu}_{3}(\mathrm{~S}, \mathrm{~S}(+) \mathrm{cpse})_{3}\left(\mathrm{H}_{2} \mathrm{O}\right)_{3}\right] \cdot 8 \mathrm{H}_{2} \mathrm{O}$ compound, $\Delta$ isomer. Proposed structures for (b) $\left[\mathrm{Cu}_{2} \mathrm{Co}(\mathrm{S}, S(+) \text { cpse })_{3}\left(\mathrm{H}_{2} \mathrm{O}\right)_{3}\right] \cdot 4 \mathrm{H}_{2} \mathrm{O}(\mathbf{1})$ and (c) $\left[\mathrm{Cu}_{2} \mathrm{Ni}(S, S(+) \text { cpse })_{3}\left(\mathrm{H}_{2} \mathrm{O}\right)_{3}\right] \cdot 10 \mathrm{H}_{2} \mathrm{O}(2)$.

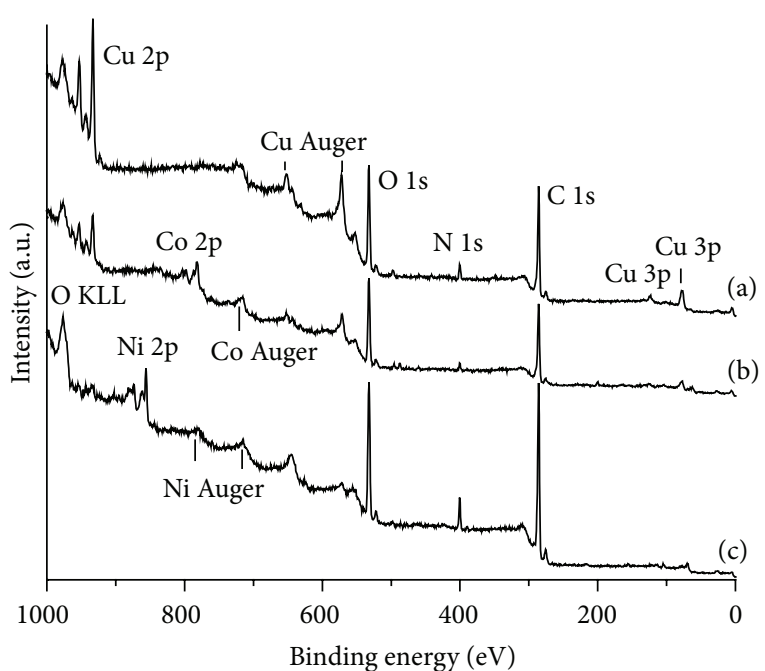

FIGURE 5: Survey XPS spectra of the homometallic and heterometallic compounds. (a) $\left[\mathrm{Cu}_{3}(\mathrm{~S}, \mathrm{~S}(+) \mathrm{cpse})_{3}\left(\mathrm{H}_{2} \mathrm{O}\right)_{3}\right] \cdot 8 \mathrm{H}_{2} \mathrm{O}$, (b) $\left[\mathrm{Cu}_{2} \mathrm{Co}(\mathrm{S}, \mathrm{S}(+) \mathrm{cpse})_{3}\left(\mathrm{H}_{2} \mathrm{O}\right)_{3}\right] \cdot 4 \mathrm{H}_{2} \mathrm{O}$ (1), and (c) $\left[\mathrm{Cu}_{2} \mathrm{Ni}(S, S(+)\right.$. cpse $\left.)_{3}\left(\mathrm{H}_{2} \mathrm{O}\right)_{3}\right] \cdot 10 \mathrm{H}_{2} \mathrm{O}(2)$.

electronegativities when substituting copper(II) by cobalt(II) or nickel(II) is not significant, but the charge transfer between metal ions is observed.
In the XPS valence band spectra for these compounds mainly two peaks are observed. The first one with a single fine structure at a binding energy of $2-8 \mathrm{eV}$ originates from photoemission out of the $\mathrm{d}^{9}$ ground state configuration of copper(II), for which the photo-hole is screened by a charge transfer from the ligand $\mathrm{O} 2 \mathrm{p}$ electrons towards the $\mathrm{Cu}$ (labelled by $\mathrm{d}^{9} \rightarrow \mathrm{d}^{9} \underline{\mathrm{L}}$ with $\underline{\mathrm{L}}$ meaning the hole in the $\mathrm{O} 2 \mathrm{p}$ ligand states L). For the three compounds there exists a contribution of copper(II). However, heterometallic compounds 1 and $\mathbf{2}$ present an additional contribution from the cobalt(II), Co $3 \mathrm{~d}(1 \mathrm{eV})$, and nickel(II) $\mathrm{Ni} 3 \mathrm{~d}(2 \mathrm{eV})$ (Figure 6). In the crystalline structure for $\left[\mathrm{Cu}_{3}(\mathrm{~S}, \mathrm{~S}(+) \mathrm{cpse})_{3}\left(\mathrm{H}_{2} \mathrm{O}\right)_{3}\right] \cdot 8 \mathrm{H}_{2} \mathrm{O}$ there exists a stable six-membered ring (Cul-O-Cu2-O-Cu3$\mathrm{O}-\mathrm{Cul}$ ) in a chair conformation (Figure 7). For this arrangement there is a higher electronic delocalization between metal ions and the oxygen atoms from of the ligand. For the heterometallic compounds this electronic delocalization is also expected. In consequence, the effect on their charge transfer is observed which is a shift to positive energy at Fermi level. The second one appears at about $14 \mathrm{eV}$ and presents contributions of the ligand.

In Figure 8, the binding energies for copper $2 \mathrm{p}_{3 / 2}, 2 \mathrm{p}_{1 / 2}$, nickel $2 \mathrm{p}_{3 / 2}, 2 \mathrm{p}_{1 / 2}$, and cobalt $2 \mathrm{p}_{3 / 2}, 2 \mathrm{p}_{1 / 2}$ levels in the three compounds are shown: $\left[\mathrm{Cu}_{3}(\mathrm{~S}, \mathrm{~S}(+) \mathrm{cpse})_{3}\left(\mathrm{H}_{2} \mathrm{O}\right)_{3}\right] \cdot 8 \mathrm{H}_{2} \mathrm{O}$, $\left[\mathrm{Cu}_{2} \mathrm{Co}(\mathrm{S}, \mathrm{S}(+) \mathrm{cpse})_{3}\left(\mathrm{H}_{2} \mathrm{O}\right)_{3}\right] \cdot 4 \mathrm{H}_{2} \mathrm{O}(\mathbf{1})$, and $\left[\mathrm{Cu}_{2} \mathrm{Ni}(\mathrm{S}, \mathrm{S}(+)\right.$. cpse $\left.)_{3}\left(\mathrm{H}_{2} \mathrm{O}\right)_{3}\right] \cdot 10 \mathrm{H}_{2} \mathrm{O}$ (2) synthesized in this work. For copper on $\left[\mathrm{Cu}_{3}(\mathrm{~S}, \mathrm{~S}(+) \text { cpse })_{3}\left(\mathrm{H}_{2} \mathrm{O}\right)_{3}\right] \cdot 8 \mathrm{H}_{2} \mathrm{O}$ compound $2 \mathrm{p}_{3 / 2}$ was found at $932.54 \mathrm{eV}$ (charge transfer shake-up satellite 


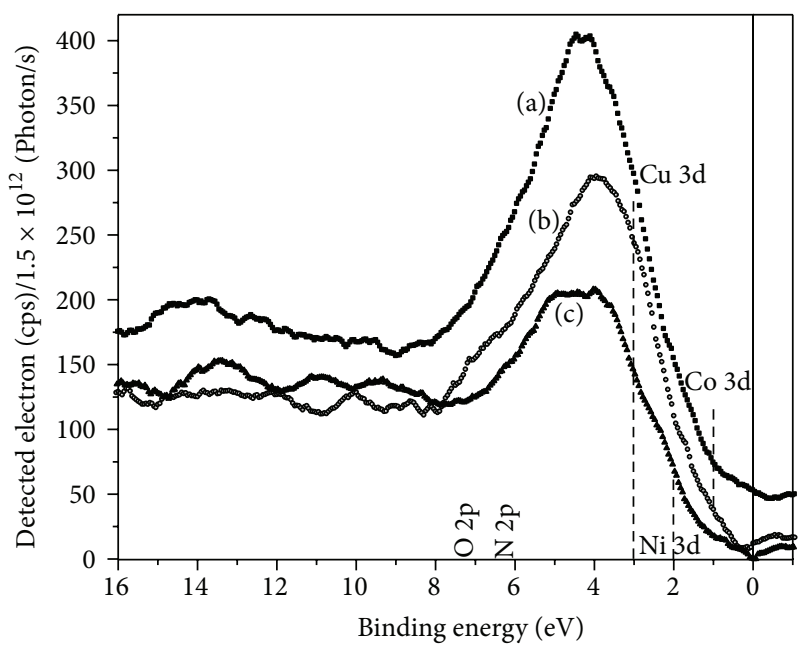

Figure 6: XPS valence band spectra of (a) $\left[\mathrm{Cu}_{3}(\mathrm{~S}, S(+) \mathrm{cpse})_{3}\right.$. $\left.\left(\mathrm{H}_{2} \mathrm{O}\right)_{3}\right] \cdot 8 \mathrm{H}_{2} \mathrm{O}$, (b) $\left[\mathrm{Cu}_{2} \mathrm{Co}(\mathrm{S}, \mathrm{S}(+) \mathrm{cpse})_{3}\left(\mathrm{H}_{2} \mathrm{O}\right)_{3}\right] \cdot 4 \mathrm{H}_{2} \mathrm{O}(\mathbf{1})$, and (c) $\left[\mathrm{Cu}_{2} \mathrm{Ni}(\mathrm{S}, \mathrm{S}(+) \text { cpse })_{3}\left(\mathrm{H}_{2} \mathrm{O}\right)_{3}\right] \cdot 10 \mathrm{H}_{2} \mathrm{O}(2)$.

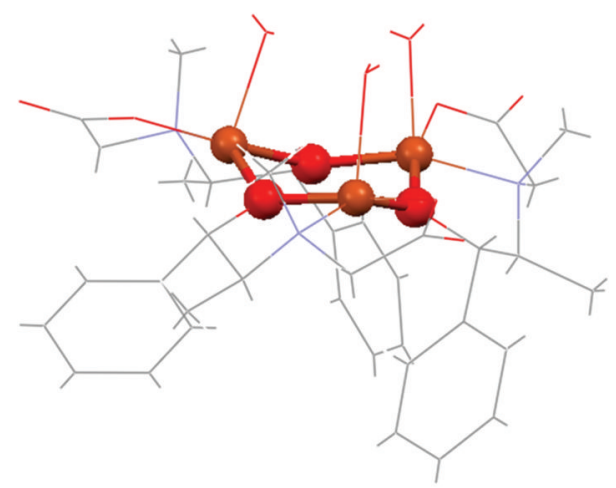

Figure 7: Chair conformation for the $\left[\mathrm{Cu}_{3}(S, S(+) \text { cpse })_{3}\left(\mathrm{H}_{2} \mathrm{O}\right)_{3}\right]$. $8 \mathrm{H}_{2} \mathrm{O}$ structure.

peak at 942.80 ) and $2 \mathrm{p}_{1 / 2}$ in $952.48 \mathrm{eV}$ (charge transfer satellite peak at $962.71 \mathrm{eV}$ ). The compounds $\mathbf{1}$ and $\mathbf{2}$ present similar peaks to those of the homotrinuclear copper(II) compound in the expected region for copper(II); therefore this behaviour suggests electronic similarities between the trinuclear compounds. The compounds $\mathbf{1}$ and $\mathbf{2}$ spectra for cobalt $(781.53 \mathrm{eV}$, charge transfer satellite peak at 786.87 and $2 \mathrm{p}_{1 / 2}$ in $797.42 \mathrm{eV}$, charge transfer satellite peak at $802.96 \mathrm{eV}$ ) and nickel $(855.20 \mathrm{eV}$, charge transfer satellite peak at 861.22 and $2 \mathrm{p}_{1 / 2}$ in $872.87 \mathrm{eV}$, charge transfer satellite peak at $879.47 \mathrm{eV}$ ) were compared with $\mathrm{CoO}$ [22] and NiO. The satellites were used as a finger print for the recognition of high-spin cobalt(II) and nickel(II). This behaviour is consistent with a $3 \mathrm{~d}^{8}$ nickel(II) ion and $3 \mathrm{~d}^{7}$ cobalt(II) ion. No evidence of other nickel(II) and cobalt(II) transitions was observed from their spectra. Hence this suggests that in these compounds the metal ions do not contain different oxidation states other than $2^{+}[23]$.
The observed binding energy of the N 1s XPS transition, at $399.93 \mathrm{eV}$, is in agreement with the reported values for organic amines coordinated with metal atoms in solid state [15]. The nitrogen atom shows a similar electronic behaviour in all studied compounds (Figure 8).

The XPS core level spectrum for $\left[\mathrm{Cu}_{3}(S, S(+) \text { cpse })_{3}\right.$. $\left.\left(\mathrm{H}_{2} \mathrm{O}\right)_{3}\right] \cdot 8 \mathrm{H}_{2} \mathrm{O}$ of the $\mathrm{C}$ 1s region shows the following order: $\left(\mathrm{C}-\mathrm{CH}_{2}\right) 285.00,\left(\mathrm{C}-\mathrm{CH}_{3}\right) 285.67,\left(\mathrm{CH}_{3}-\mathrm{N}\right) 285.96 \mathrm{eV}$, $\left(\mathrm{CH}_{2}-\mathrm{N}\right)$ 286.46, (C-O-M; $\mathrm{M}=$ metal ion) $287.20 \mathrm{eV}$, and $(\mathrm{C}=\mathrm{O}) 289.09 \mathrm{eV}$. The binding energy depends on the specific environment where the functional groups are located. In this context, it is found that $\mathrm{C}-\mathrm{C}$ is after of $\mathrm{C}-\mathrm{N}$ and $\mathrm{C}-\mathrm{O}$. The increase in bond polarity leads shifted to higher energy. These contributions for Cls level show coordination of the ligand towards metal by nitrogen and oxygen atoms (Figure 9).

For $\mathbf{O} 1 s$ core level the binding energy corresponding to $(\mathrm{O}-\mathrm{Cu}-\mathrm{O}) 530.79 \mathrm{eV},(\mathrm{C}=\mathrm{O}) 531.67 \mathrm{eV},(\mathrm{C}-\mathrm{O}) 532.38 \mathrm{eV}$, $\left(\mathrm{H}_{2} \mathrm{O}-\mathrm{Cu}\right) 533.36$, and satellite at $532.50 \mathrm{eV}$ are shown. The allocations were realized for trinuclear copper(II) compound. For compound 1 contributions for $\mathrm{O}-\mathrm{Co}-\mathrm{O}$ and compound $2 \mathrm{O}-\mathrm{Ni}-\mathrm{O}$ are additionally observed (Figure 10 ). Contributions due to $\mathrm{H}_{2} \mathrm{O}$ molecule are correlated with the amount of molecules outside the coordination sphere: compound $\mathbf{2}>$ trinuclear copper(II) compound > compound $\mathbf{1}$.

3.2. Magnetic Properties of the Trinuclear Compounds for 1 and 2. To investigate the magnetic interactions in the heterotrinuclear compounds, EPR spectra and the magnetic susceptibilities of powdered samples were measured from 4 to $300 \mathrm{~K}$.

The EPR spectrum at $115 \mathrm{~K}$ for $\left[\mathrm{Cu}_{2} \mathrm{Co}(S, S(+) \mathrm{cpse})_{3}\right.$. $\left.\left(\mathrm{H}_{2} \mathrm{O}\right)_{3}\right] \cdot 4 \mathrm{H}_{2} \mathrm{O}(\mathbf{1})$ corresponds to a high-spin $\mathrm{d}^{7}$ configuration either in an orbitally nondegenerate ground state $\left({ }^{4} \mathbf{A}_{2}\right)$ or in an orbitally degenerate ground state $\left({ }^{4} \mathrm{~T}_{1}\right)$ in which the orbital levels are separated by spin-orbit coupling. The orbital angular moment is quenched, and the combined effects of crystal field symmetry and mixture of excited terms through second-order spin-orbit may lead to a splitting the two doublets. The resonance absorption features appear at $g$ value $\sim 5.6,3.4$ and splitting $~ 2.09$. Hyperfine structure resolved in both $\sim 5.6$ and $\sim 2.09$ regions corresponds to a coupling for the cobalt(II) $I=7 / 2$. However, the EPR spectra depicted in Figure 11 show the overlap signals for copper(II) and cobalt(II) for pentacoordinate complexes of high spin.

The plot of $\chi_{M} T$ versus $T(300-4 \mathrm{~K})$, show a change in the slope. It involves an increase in $\chi_{M} T$ as temperature is lowered, followed by a rapid drop at temperatures $<13.75 \mathrm{~K}$. The drop in $\chi_{M} T$ below $17 \mathrm{~K}$ suggests the presence of a weak intermolecular antiferromagnetic interaction, but after $17 \mathrm{~K}$ the ferromagnetic behaviour is shown (Figure 12). This compound presents a magnetic moment of 8.15 B.M. at $298 \mathrm{~K}$, per all metallic atoms, which is indicating the contribution of the copper(II) and cobalt(II) atoms.

For compound $\left[\mathrm{Cu}_{2} \mathrm{Ni}(\mathrm{S}, \mathrm{S}(+) \mathrm{cpse})_{3}\left(\mathrm{H}_{2} \mathrm{O}\right)_{3}\right] \cdot 10 \mathrm{H}_{2} \mathrm{O}(2)$, in the EPR spectrum at $115 \mathrm{~K} g_{\|}>g_{\perp}>g_{\mathrm{e}}(2.0023)$ suggest that the un pair electron is localized in $d x^{2}-y^{2}$ orbital of $\mathrm{Cu}(\mathrm{II})$ ions and the spectral features are characteristics of axial symmetry. The complex under study may have square 

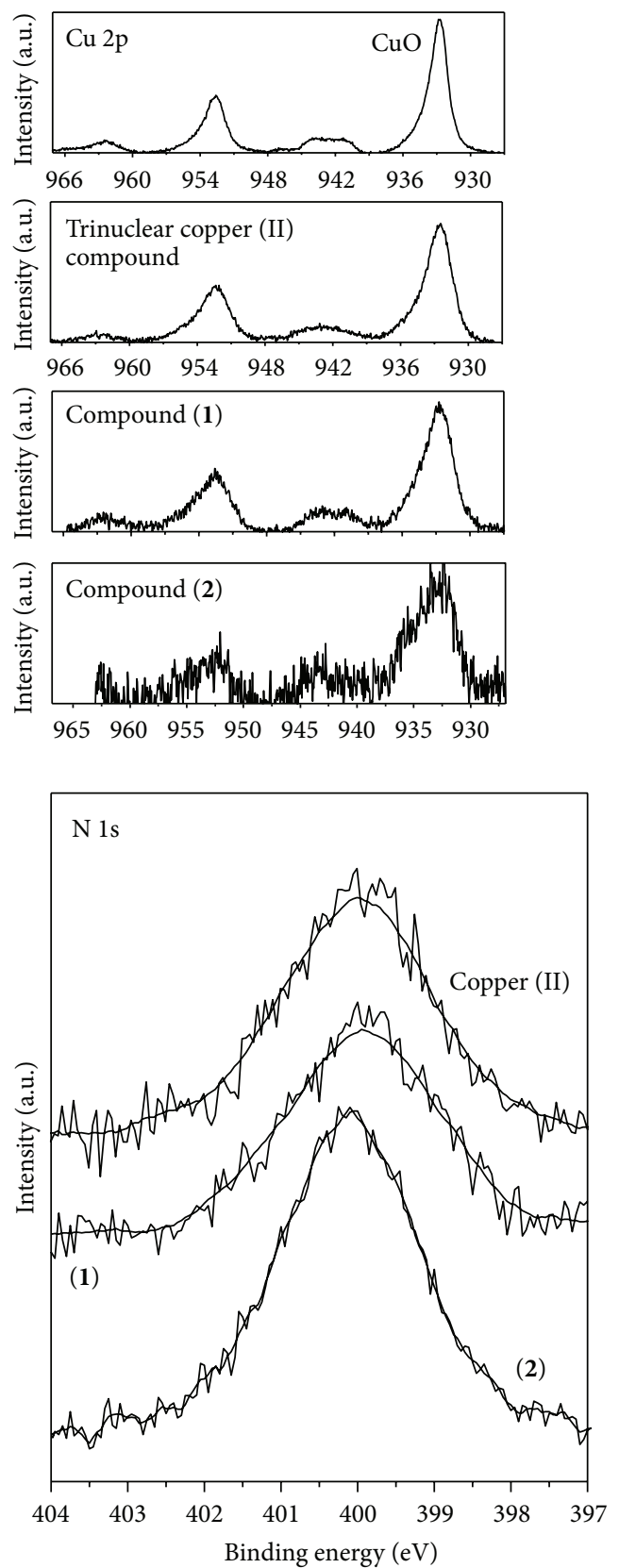
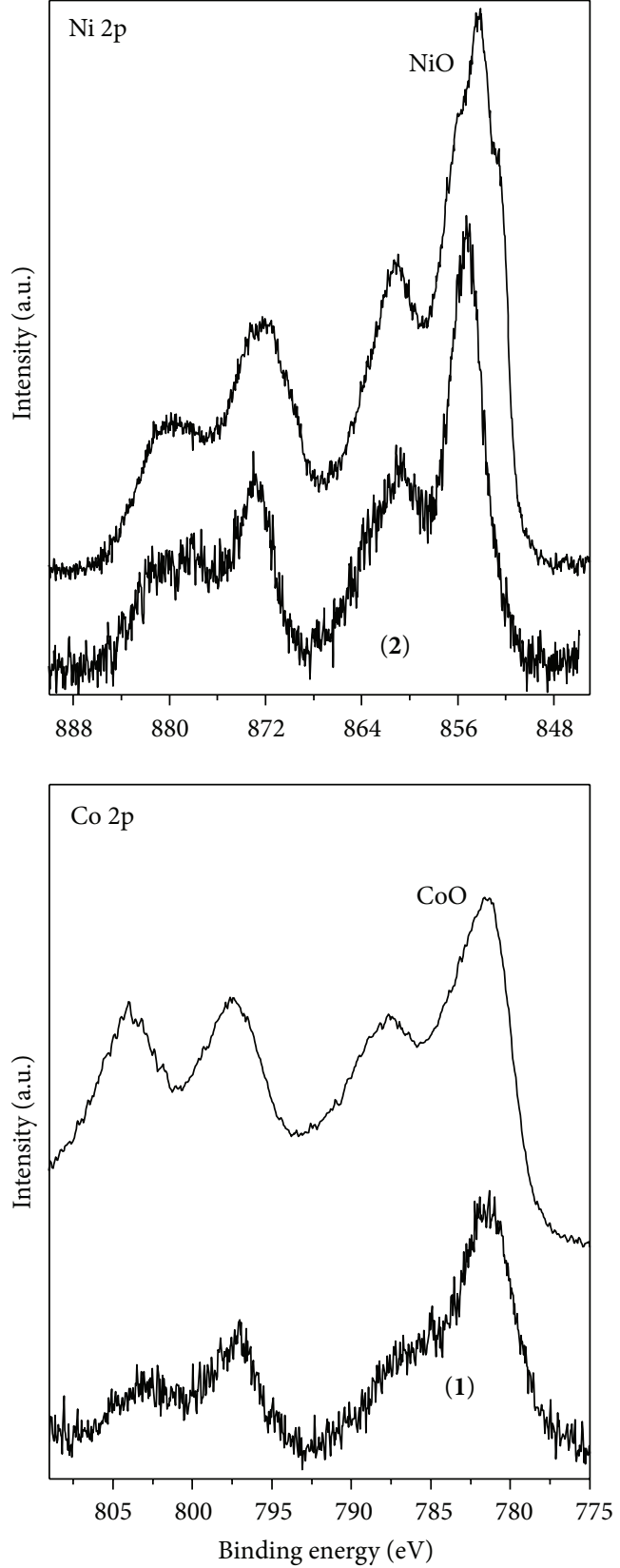

FIGURE 8: XPS spectra of Cu 2p, Ni 2p, Co 2p, and N 1s core level. Compared with the XPS spectra of the homotrinuclear and heterotrinuclear compounds (1) and (2).

pyramidal geometry in the copper(II) atoms. The value of $R$ parameter $\left(g_{2}-g_{1} / g_{3}-g_{2}\right)$ is indicating ${ }^{2} \mathrm{~B}_{1}$ as ground state; thus less than one. For nickel(II) with $S=1$ signals around of $1000 \mathrm{G}$ are expected (Figure 13). The magnetic moment of five coordinated $\mathrm{Cu}(\mathrm{II})-\mathrm{Cu}(\mathrm{II})-\mathrm{Ni}(\mathrm{II})$ complexes at room temperature of 6.15 B.M is representing antiferromagnetic behaviour between metal centres.

The plot $\chi_{M} T$ versus $T$, between $300-4 \mathrm{~K}$, is depicted in Figure 14. It shows an antiferromagnetic behaviour. The experimental data were fitted with the expression derived from the Hamiltonian (1) which corresponds to a triangular array of $\mathrm{Cu}-\mathrm{Cu}-\mathrm{Ni}$ spins: the best fit parameters being $J=$ $-4.9 \mathrm{~cm}^{-1}, g=1.696$,

$$
\begin{aligned}
x_{M} T & \\
= & \frac{N g^{2} \beta^{2}}{3 k} \\
& \times \frac{6 \exp (J / K T)+6 \exp (2 J / K T)+30 \exp (2 J / K T)}{1+3 \exp (J / K T)+3 \exp (2 J / K T)+5 \exp (3 J / K T)} .
\end{aligned}
$$



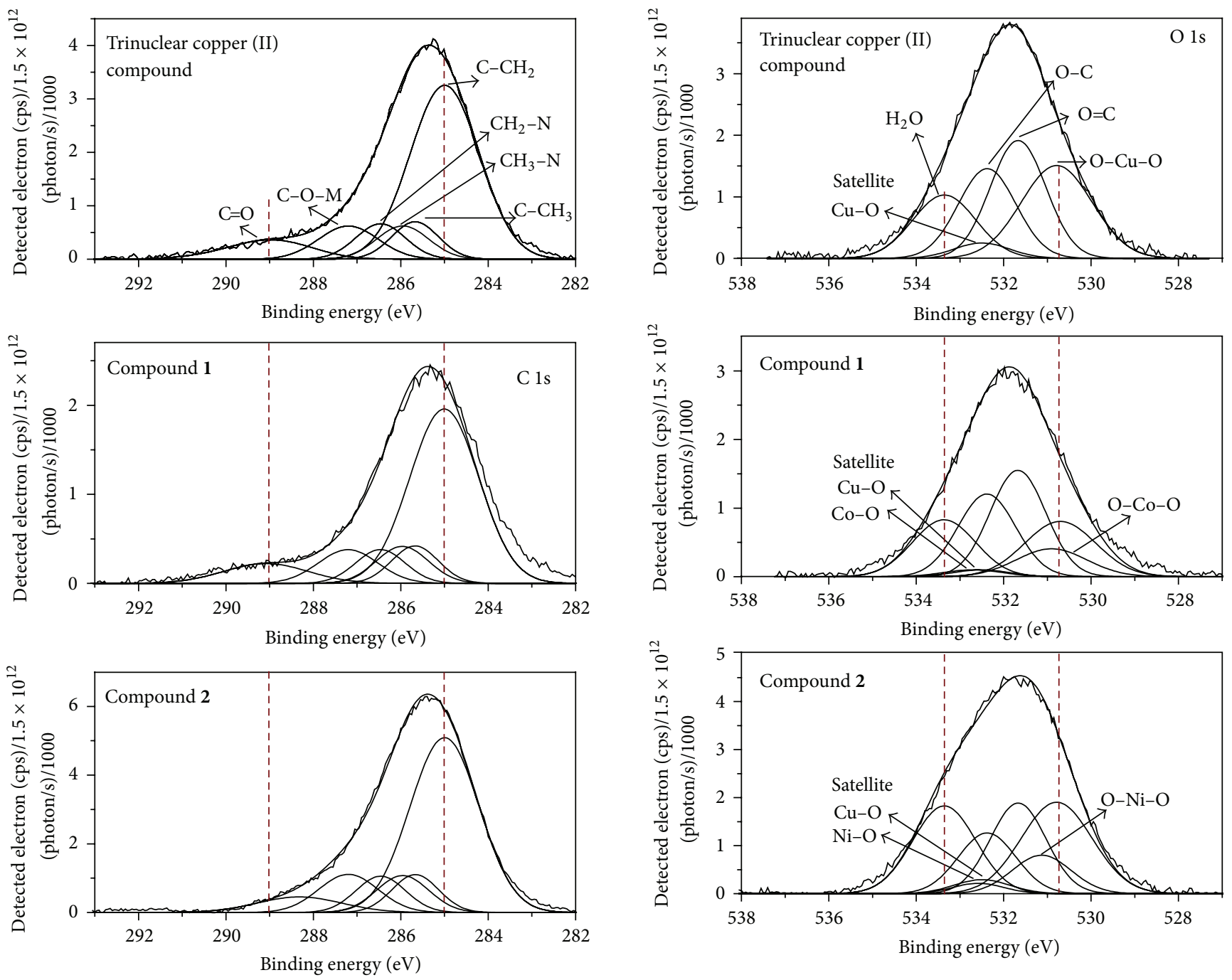

FIgURE 9: XPS spectra for $\mathrm{C} 1 \mathrm{~s}$ core level in $\left[\mathrm{Cu}_{3}(S, S(+) \text { cpse })_{3}\right.$. $\left.\left(\mathrm{H}_{2} \mathrm{O}\right)_{3}\right] \cdot 8 \mathrm{H}_{2} \mathrm{O}$ for compounds $\mathbf{1}$ and 2 .

\section{Conclusions}

Cobalt-copper and nickel-copper trinuclear heterometallic compounds, with the chiral ligand $(S, S(+)$ cpse), were studied by photoelectron spectroscopy (XPS). The found core levels for $\mathrm{Cu} 2 \mathrm{p}, \mathrm{Ni} 2 \mathrm{p}, \mathrm{Co} 2 \mathrm{p}, \mathrm{C} 1 \mathrm{~s}, \mathrm{O}$ 1s, and $\mathrm{N}$ 1s led to the the identification the chemical structure in correspondence with the crystalline structure for homotrinuclear copper(II) compound. In the valence band, the effects due to charge transfer between the metal ions and the ligand were found. These results were in agreement with the spectroscopic and analytical characterization (IR, UV-V is reflectance diffuse, elemental analysis, and atomic absorption). The substitution of a copper(II) atom by one the cobalt(II) ion gave place to a heterometallic compound $\mathbf{1}$, which is ferromagneticantiferromagnetic magnetic transition. The substitution of a copper(II) atom by one the nickel(II) atom in compound 1, showed an antiferromagnetic coupling. The magnetic behaviour of the heterotrinuclear compounds is driven by

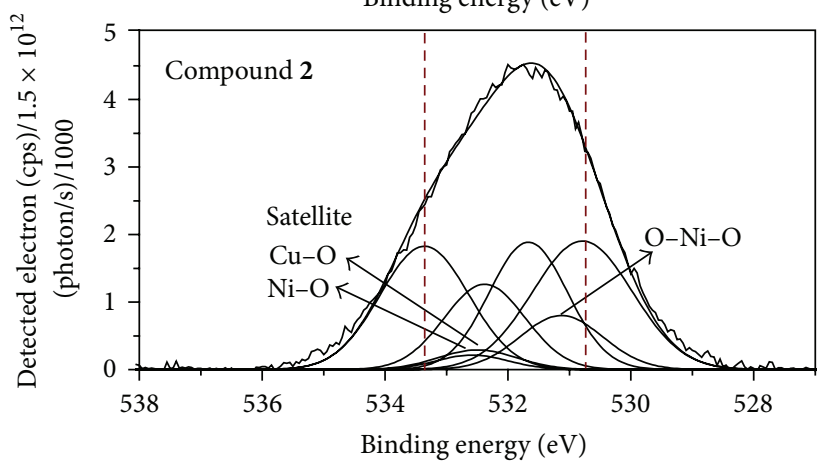

FIGURE 10: XPS spectra O1s core level for $\left[\mathrm{Cu}_{3}(\mathrm{~S}, \mathrm{~S}(+) \mathrm{cpse})_{3}\left(\mathrm{H}_{2} \mathrm{O}\right)_{3}\right]$. $8 \mathrm{H}_{2} \mathrm{O}$ and compounds $\mathbf{1}$ and 2 .
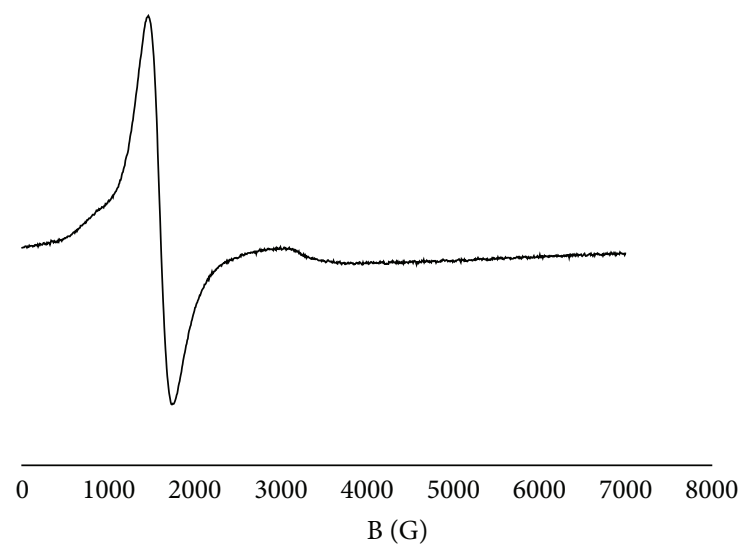

FIGURE 11: EPR spectrum for $\left[\mathrm{Cu}_{2} \mathrm{Co}(\mathrm{S}, \mathrm{S}(+) \mathrm{cpse})_{3}\left(\mathrm{H}_{2} \mathrm{O}\right)_{3}\right] \cdot 4 \mathrm{H}_{2} \mathrm{O}$ (1). 


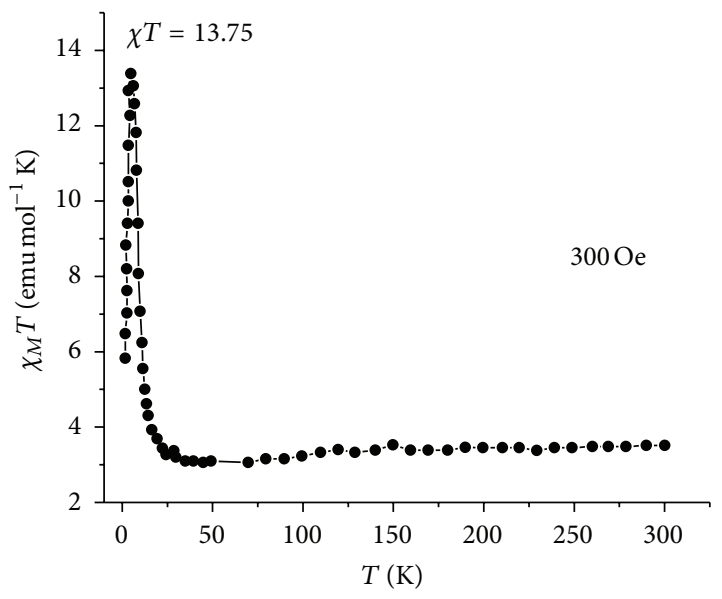

Figure 12: Temperature dependence of $\chi_{M} T$ versus $T$ for $\left[\mathrm{Cu}_{2} \mathrm{Co}(\mathrm{S}, \mathrm{S}(+) \text { cpse })_{3}\left(\mathrm{H}_{2} \mathrm{O}\right)_{3}\right] \cdot 4 \mathrm{H}_{2} \mathrm{O}(\mathbf{1})$.

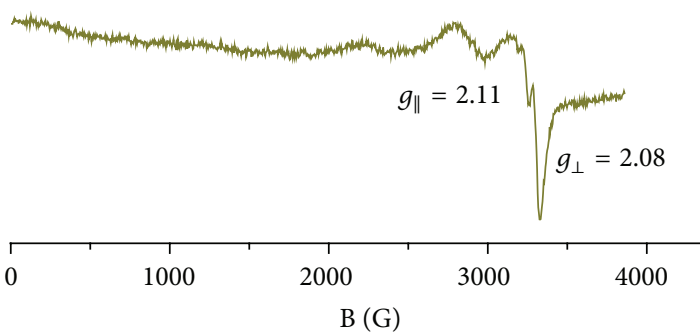

Figure 13: EPR spectrum for $\left[\mathrm{Cu}_{2} \mathrm{Ni}(\mathrm{S}, \mathrm{S}(+) \text { cpse })_{3}\left(\mathrm{H}_{2} \mathrm{O}\right)_{3}\right] \cdot 9 \mathrm{H}_{2} \mathrm{O}$ (2).

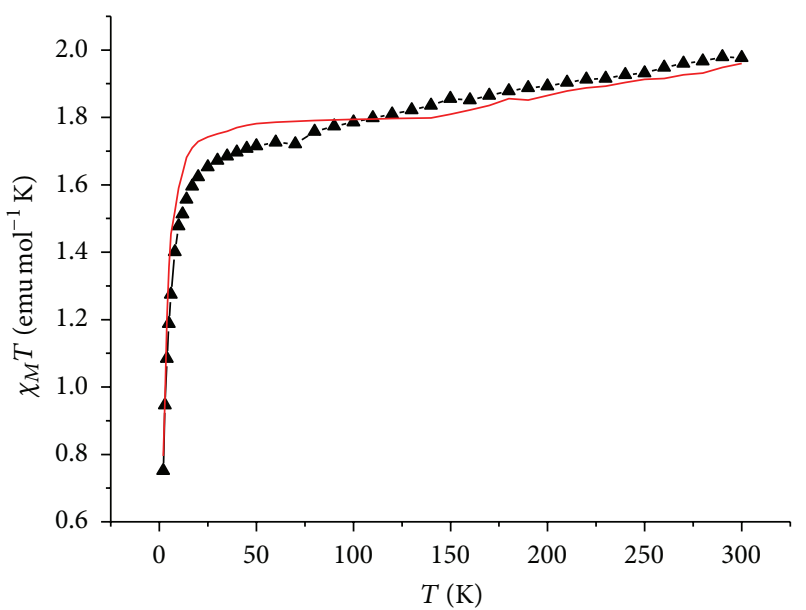

FIgURE 14: Temperature dependence of $\chi_{M} T$ versus $T$ for $\left[\mathrm{Cu}_{2} \mathrm{Ni}(S, S(+) \text { cpse })_{3}\left(\mathrm{H}_{2} \mathrm{O}\right)_{3}\right] \cdot 9 \mathrm{H}_{2} \mathrm{O}$ (2). The solid line shows the theoretical susceptibility calculated by (1).

the nature of the metal ion which was introduced in the copper(II) triangular array.

\section{Acknowledgments}

The authors would like to thank CONACyT for student fellowships to Yenny Ávila-Torres, Ramón Vicente (Universitat de Barcelona) for magnetic measurements, Israel Betancourt (IIM-UNAM) for academic support, and Rosalinda Contreras (CINVESTAV) for synthesis of chiral ligands, and Horacio López Sandoval (F.Q. UNAM), and the financial support by DGAPA (Grant IN212210 to Noráh Barba-Behrens) is acknowledged.

\section{References}

[1] Y. Jack, Lu. Michael, A. Lawandy, and L. Jing, “ New type of two-dimensional metal coordination systems: hydrothermal synthesis and properties of the first oxalate-bpy mixed-ligand framework ${ }_{\infty}^{2}[\mathrm{M}(\mathrm{ox})(\mathrm{bpy})](\mathrm{M}=\mathrm{Fe}(\mathrm{II}), \mathrm{Co}(\mathrm{II}), \mathrm{Ni}(\mathrm{II}), \mathrm{Zn}(\mathrm{II})$; $\mathrm{ox}=\mathrm{C}_{2} \mathrm{O}_{4}^{2-}$; bpy $=4,4^{\prime}$-bipyridine)," Inorganic Chemistry, vol. 38, no. 11, pp. 2695-2704, 1999.

[2] W. Kaim, A. Klein, and M. Glockle, "Exploration of mixedvalence chemistry: inventing new analogues of the CreutzTaube ion," Accounts of Chemical Research, vol. 33, no. 11, pp. 755-763, 2000.

[3] J. R. Gispert, Coordination Chemistry, John Wiley \& Sons, Hoboken, NJ, USA, 2008.

[4] Y.-S. Yang, W. Gu, L.-Z. Zhang, F.-X. Gao, and S.-P. Yan, "A new oxamato-bridged heterotrinuclear NiIICuIINiII complex: synthesis, structure and properties," Journal of Coordination Chemistry, vol. 61, no. 4, pp. 571-578, 2008.

[5] P. Pietrzyk, M. Srebro, M. Radoń, Z. Sojka, and A. Michalak, "Spin ground state and magnetic properties of cobalt(II): relativistic DFT calculations guided by EPR measurements of bis(2,4-acetylacetonate)cobalt(II)- based complexes," Journal of Physical Chemistry A, vol. 115, no. 11, pp. 2316-2324, 2011.

[6] O. Kahn and C. J. Martínez, "Spin-transition polymers: from molecular materials toward memory devices," Science, vol. 279, no. 5347, pp. 44-48, 1998.

[7] Y. . Sunatsuki, Y. Ikuta, N. Matsumoto et al., "An unprecedented homochiral mixed-valence spin-crossover compound," Angewandte Chemie, vol. 115, pp. 1652-1656, 2003.

[8] M. Z. Alam, T. Yoshioka, T. Ogata, T. Nonaka, and S. Kurihara, "Influence of helical twisting power on the photoswitching behavior of chiral azobenzene compounds: applications to high-performance switching devices," Chemistry A, vol. 13, no. 9, pp. 2641-2647, 2007.

[9] B. Kesanli and W. Lin, "Chiral porous coordination networks: rational design and applications in enantioselective processes," Coordination Chemistry Reviews, vol. 246, no. 1-2, pp. 305-326, 2003.

[10] M. Eddaoudi, D. B. Moler, H. Li et al., "Modular chemistry: secondary building units as a basis for the design of highly porous and robust metal-organic carboxylate frameworks," Accounts of Chemical Research, vol. 34, no. 4, pp. 319-330, 2001.

[11] Q. Yue, J. Yang, G.-H. Li et al., "Three-dimensional 3d-4f heterometallic coordination polymers: synthesis, structures, and magnetic properties," Inorganic Chemistry, vol. 44, no. 15, pp. 5241-5246, 2005.

[12] H. López-Sandoval, R. Contreras, A. Escuer et al., "Synthesis, crystal structure and magnetic properties of the triangulotricopper(II) complex $\left[\mathrm{Cu}_{3}(\mathrm{cpse})_{3}\left(\mathrm{H}_{2} \mathrm{O}\right)_{3}\right] \cdot 8.5 \mathrm{H}_{2} \mathrm{O}$," Dalton Transactions, no. 13, pp. 2648-2653, 2002. 
[13] R. Contreras, A. Flores-Parra, H. C. López-Sandoval, and N. Barba-Behrens, "Ephedrine derivatives, extraordinary tools for the study of stereogenic centers in tetra- to heptacoordinated complexes," Coordination Chemistry Reviews, vol. 251, no. 13-14, pp. 1852-1867, 2007.

[14] F. Reinert and S. Hüfner, "Photoemission spectroscopy-from early days to recent applications," New Journal of Physics, vol. 7, p. 97, 2005.

[15] E. I. Solomon, L. Basumallick, P. Chen, and P. Kennepohl, "Variable energy photoelectron spectroscopy: electronic structure and electronic relaxation," Coordination Chemistry Reviews, vol. 249, no. 1-2, pp. 229-253, 2005.

[16] F. de Groot and A. Kotani, Core Level Spectroscopy of Solids, CRC Press, New York, NY, USA, 2008.

[17] SDP v4.1 (32 bit) Copyright 2004, XPS International, Compiled in January 2004.

[18] H. López-Sandoval, N. Barba-Behrens, S. Bernès, N. FarfánGarcía, and H. Höpth, "Co-ordination behaviour of $\mathrm{N}$ carboxymethylpseudoephedrine: crystal structures of sevenco-ordinated cadmium(II) and fac-RS-octahedral copper(II) complexes," Dalton Transactions, no. 19, pp. 3415-3420, 1997.

[19] K. Nakamoto, Infrared and Raman Spectra of Inorganic and Coordination Compounds, John Wiley \& Sons, New York, NY, USA, 4th edition, 1986.

[20] A. B. P. Lever, Inorganic Electronic Spectroscopy, Elsevier, Amsterdam, The Netherlands, 2nd edition, 1986.

[21] W. F. Egelhoff Jr., "Core-level binding-energy shifts at surfaces and in solids," Surface Science Reports, vol. 6, pp. 253-415, 1987.

[22] E. E. Khawaja, S. M. A. Durrami, F. F. Al-Adel, M. A. Salimi, and S. Hussaim, "X-ray photoelectron spectroscopy and Fourier transform-infrared studies of transition metal phosphate glasses," Journal of Materials Science, vol. 30, no. 1, pp. 225-234, 1995.

[23] G. Long and R. D. Willelt, "Electrochemical synthesis, characterization and magnetic studies of Ni/TCNQ salts," Inorganica Chimica Acta, vol. 313, pp. 1-14, 2001. 

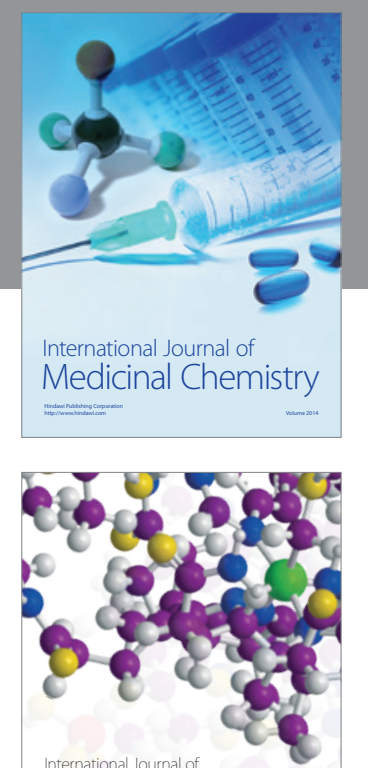

\section{Carbohydrate} Chemistry

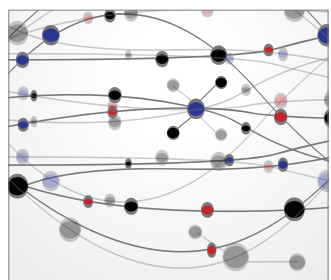

The Scientific World Journal
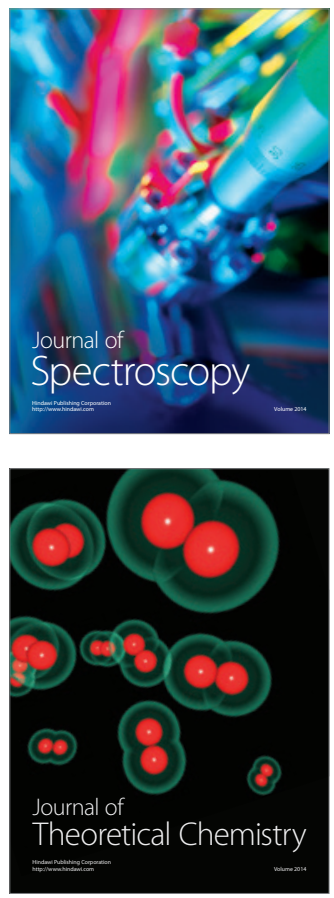
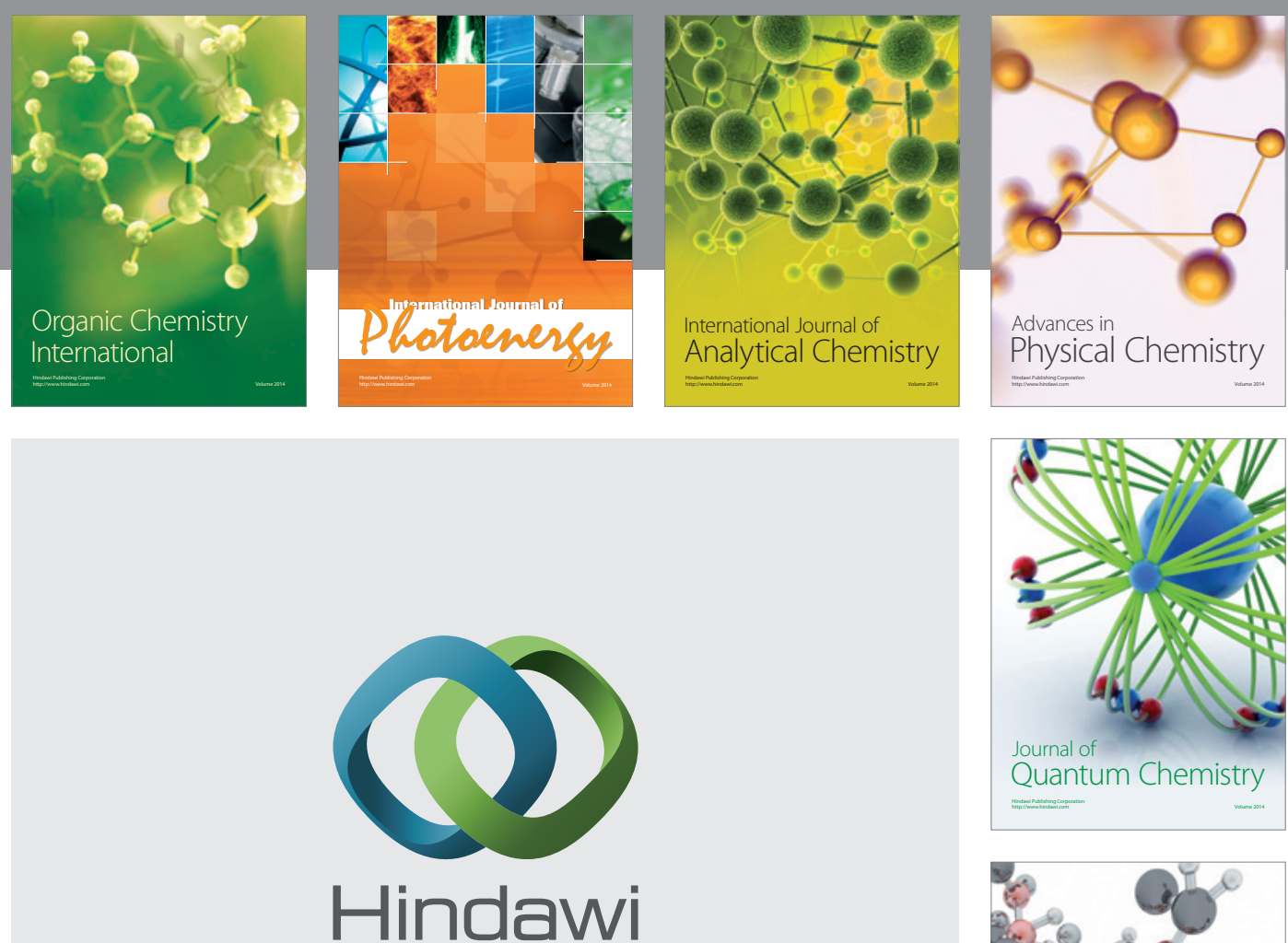

Submit your manuscripts at

http://www.hindawi.com

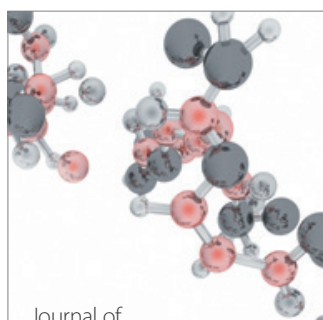

Analytical Methods

in Chemistry

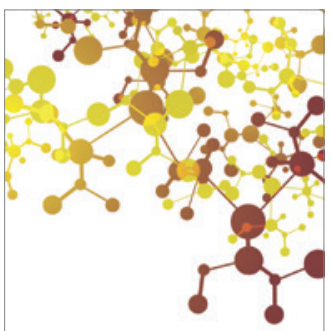

Journal of

Applied Chemistry

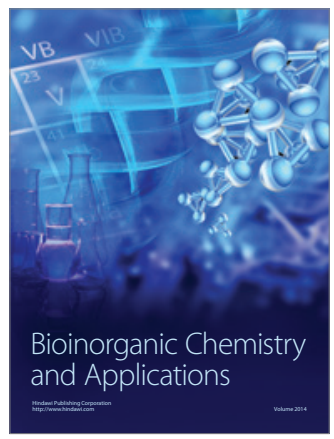

Inorganic Chemistry
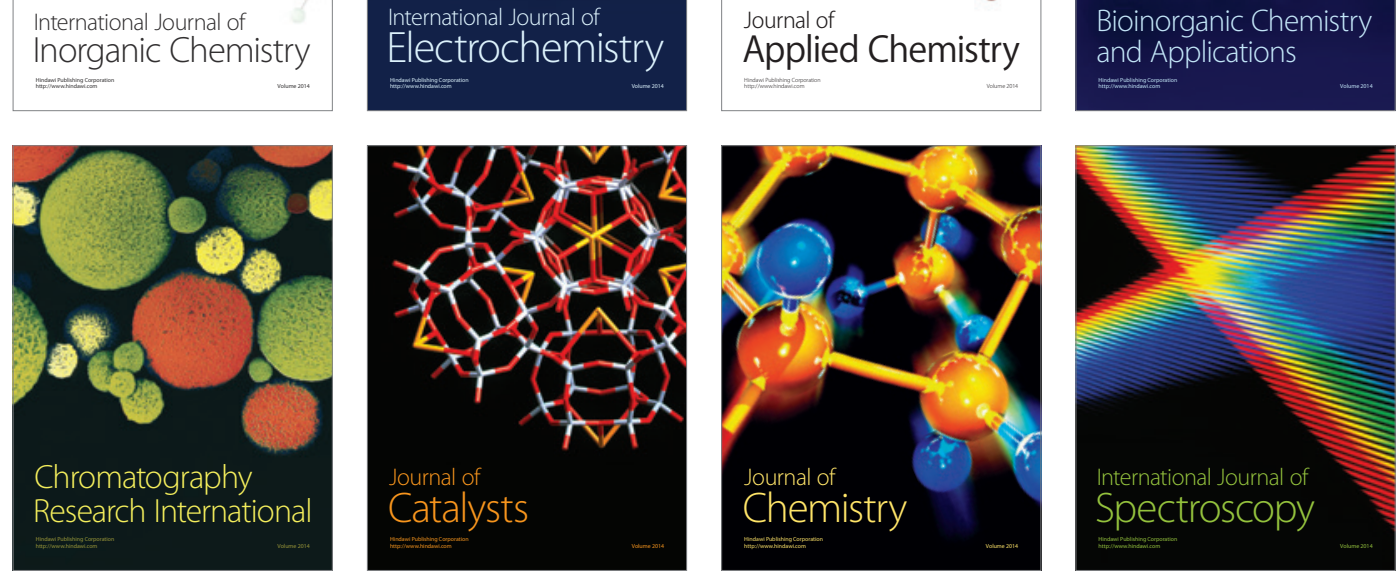